\title{
Evaluation of Sterilant Effect on In-vitro Culture Establishment in Sugarcane Variety Co 0118
}

\author{
Devendra Kumar ${ }^{1 *}$, Rakesh Singh Sengar ${ }^{1}$, Manoj Kumar Yadav ${ }^{1}$, Pooranchand ${ }^{2}$, \\ Gopal Singh ${ }^{3}$ and Shalani Gupta ${ }^{4}$
}
${ }^{1}$ Department of Agricultural Biotechnology, ${ }^{2}$ Department of Genetics and Plant Breeding, ${ }^{3}$ Department of Plant Pathology, ${ }^{4}$ Department of Molecular Biology and Genetic Engineering, College of Biotechnology, S.V.P.U.A. \& T., Meerut- 250110 (U.P.), India

*Corresponding author

\section{A B S T R A C T}

Keywords

Sterilization,

Culture,

Contamination,

Meristem shoot,

Sterilants

Article Info

Accepted:

10 June 2019

Available Online:

10 July 2019
In-vitro propagation is widely used as reliable alternative for true-to-type and quality seed production in sugarcane. The main obstacle under in-vitro propagation is growth of contaminants, resulting in failure of culture establishment that can be minimized by effective surface sterilization method. The sterilization process varied species to species and explants type thus, present study was designed to evaluate the effects of various sterilants on in-vitro culture establishment of sugarcane variety Co 0118 through meristem shoot tip. The explants were collected and treated with different concentrations of sterilants viz., Bavistin $^{\mathrm{TM}}$ (0.01-0.4\%), $\mathrm{HgCl}_{2}(0.01-0.4 \%), \mathrm{NaOCl}$ (2-10\%) and $\mathrm{EtOH}$ (60$100 \%)$. The treated explants were inoculated on semi solid MS media supplemented with $0.5 \mathrm{mg} / \mathrm{L}$ each of BAP and $\mathrm{Kn}$. The results obtained under study showed significant differences in their activity. The optimum culture survival percent and lower contamination with reduced necrosis was to be found when explants were treated with the combination of $0.1 \%$ Bavistin for $10 \mathrm{~min}$ followed by $0.1 \% \mathrm{HgCl}_{2}$ for $5 \mathrm{~min}, 6 \% \mathrm{NaOCl}$ for $10 \mathrm{~min}$ and $70 \% \mathrm{EtOH}$ for 1 min. This sterilization protocol will be contributive in efficient surface sterilization for in-vitro propagation of sugarcane though meristem shoot tip.

\section{Introduction}

Sugarcane is an economically important cash crop and used as one of the principal sources of sugar, ethanol, and jaggery in Indian subcontinent (Gallo-Meagher et al., 2000). It is widely grown crop in tropical and subtropical regions of the world contributing about $70 \%$ of the world sugar production (Chatenet et al., 2001). Worldwide, sugarcane is cultivated over 110 countries with an area of 25.98 million ha, and production of 1841.52 million metric tonnes. India is the second largest producer of sugarcane occupies 4.39 
million ha area with the production of 306.07 million tonnes (FAOSTAT, 2017). The usefulness of this crop makes it unique for intensive and extensive field plantation.

Generally, sugarcane is propagated through multiple cuttings of stalks. The vegetative cultivation practices are results in low multiplication rate and facilitate the source of survival for many pathogens in sugarcane setts (Schenck and Lehrer, 2000; Sengar et al., 2011). Sugarcane production is negatively affected by diseases mainly due to its vegetative propagation. Now days, in-vitro propagation through tissue culture has been established as an efficient and reliable strategy. Tissue culture not only reduces the time of multiplication but also produce trueto-type plants and can be used an alternative for rapid propagation of sugarcane (Jalaja, 2008; Sengar et al., 2012). Thus, propagation procedure of sugarcane through tissue culture should be developed in more advanced and efficient to get higher establishment.

The plants brought from the field in laboratory have high number of contaminations on their surface. These contaminants have a negative effect on explants survival and compete with in-vitro plantlets for nutrition if the proper treatment not given for their removal. Microbial contaminations reduce the mortality of in-vitro cultures and cause necrosis. The explants propagation without using any sterilant results in very less culture survival sometimes no culture survival. The prevalence of contamination makes culture establishment vulnerable in achieving goal. In successfulness of in-vitro culture establishment primary consideration given to explants selection and secondary to the suitable sterilizing agents. The chemical agent selection should of be the type that could remove contamination properly (Panhwar, 2005), and ensure higher survival rate after treatment. Development of aseptic culture protocol is a critical step to avoid the invasion and growth of contaminants. However, many protocols had been established for in-vitro propagation of sugarcane varieties (George and Tripepi, 2001; Sawant and Tawar, 2011; Ghatge et al., 2014; Belete and Kalu, 2015: Thorat et al., 2016) but looking for better optimization of sterilant combination is mandatory to achieve sustainable micropropagation. Thus present study was conducted to optimize surface sterilization for in-vitro establishment of sugarcane through meristem tip culture.

\section{Materials and Methods}

\section{Experimental plants and protocol}

The present investigation was conducted at Tissue culture laboratory, Department of Agricultural Biotechnology, College of Agriculture, SVPUA\&T, Meerut. The explants were collected from nine month old sugarcane plants Co 0118 in the form of upper tops from ShriRam Sugarcane Research Farm, Modipuram, Meerut, UP, India. MS (Murashige and Skoog) basal medium was prepared by supplementing 3\% sucrose, 300mg/L PVP, $100 \mathrm{mg} / \mathrm{L}$ myo-inositol, agar $(8 \mathrm{~g} / \mathrm{L})$ as solidifying agent along with 0.5 $\mathrm{mg} / \mathrm{L}$ each of BAP and $\mathrm{Kn}$ and $\mathrm{pH}$ adjusted to 5.8, autoclaved at $121^{\circ} \mathrm{C}$ and $15 \mathrm{lbs}(101 \mathrm{kpa})$ for 20 minutes before 3 days of inoculation. The autoclaved media was poured into presterilized culture tubes $(150 \times 25 \mathrm{~mm})$. After 3 days media was screened to check any contamination.

\section{Explant sterilization and sterilants}

The collected sugarcane tops were excised into $6-8 \mathrm{~cm}$ long spindles containing apical meristem shoot tip and thoroughly washed under running tap water for $30 \mathrm{~min}$. Initially these segments were treated with Lavolene (5\% Calcium Hypochlorite) for $10 \mathrm{~min}$ and rinsed with water to remove any traces of 
detergent. Then these segments were dipped into $0.1 \%$ Polyvinyl pyrilidone (PVP) solution and further surface sterilization treatments were given under laminar air flow hood. The explants were treated with various concentrations and combination of sterilants viz. Bavistin ${ }^{\mathrm{TM}}(0.01,0.05,0.1,0.2$ and $04 \%)$, Mercuric chloride $(0.01,0.05,0.1,0.2$ and $0.4 \%)$, Sodium hypochlorite $(2,4,6,8$ and $10 \%)$ and Ethanol (60, 70, 80, 90 and 100\%) to optimize minimum contamination, explant survival and culture establishment (Table 1). The explants were washed three times with autoclaved de-ionized water after each treatment. The explants were prepared by carefully removing upper extended outer leaf sheaths and excised without disturbing upper meristematic shoot bud using scalpel blade in 1.5-2.0 cm. The prepared explants were immediately inoculated on semisolid MS medium containing $0.5 \mathrm{mg} / \mathrm{L}$ of each BAP and $\mathrm{Kn}$ and incubated in culture room under white fluorescent light intensity of 4000 lux, 16 h of light and $8 \mathrm{~h}$ of dark photoperiod, 50-60\% RH and $25 \pm 2{ }^{\circ} \mathrm{C}$ temperature. The cultures were observed on regular interval of 3 days for contamination for four weeks and data was collected for contaminated, survived cultures.

Culture survival percent was calculated as per the formula:

Culture Survival
$\frac{\text { number of explantsurvived }}{\text { numberof explant inoculated }} \times 100$

\section{Statistical analysis}

The data was analyzed using SPSS (computer software package version 20.0) and one way ANOVA was applied to test mean differences among all treatments followed by Tukey's-b multiple range test and represented as mean \pm SE. The value $p \leq 0.05$ was considered statistically significant in each case.

\section{Results and Discussion}

In-vitro culture establishment is primarily dependant of sterilization procedures. The explants collected from field contain many microbes on their surface because plant faces every type of situation in field condition. The culture medium used in the tissue culture is most suitable for microbial growth thus, surface sterilization of collected explants is necessary. Under present study, various concentrations of sterilants and their combination had been optimized for higher culture survival and establishment (Table 1).

Bavistin, a fungicide widely used as sterilant in plant tissue culture studies (Altan et al., 2010; Khatun et al., 2016) has been used under study in different concentrations for 10 min for explants surface sterilization. Analysis of variance indicates culture survival percent range from 26.8 to $55.4 \%$ (Table 1 and Fig. 1).

A significantly $(p<0.05)$ higher culture survival percent $(55.4 \%)$ and healthy uniform shoots growth as compared to other Bavistin treatments was observed in explants treated with $0.1 \%$ Bavistin. However, the culture survival percent did not differ significantly $(p>0.05)$ in explants treated with 0.05 and $0.1 \%$ Bavistin. A significantly $(p<0.05)$ lesser survival percent was to be noted in explants treated with $0.01 \%$ Bavistin and significantly $(p<0.05)$ lesser contamination was recorded to be $0.2 \%$ treated explants but shoot induction was found to be impaired.

Mercuric Chloride $\left(\mathrm{HgCl}_{2}\right)$, a corrosive chemical compound used as disinfectant and had been reported as sterilant in plant tissue culture studies by many researchers (Preethi et al., 2011; Anburaj et al., 2011). 
Table.1 Effect of various treatments on survival and growth pattern of cultures

\begin{tabular}{|c|c|c|c|c|}
\hline Sterilants & $\begin{array}{c}\text { Concentraion } \\
(\%)\end{array}$ & Time (min) & $\begin{array}{l}\text { Survival } \\
(\%)\end{array}$ & $\begin{array}{l}\text { Shoot induction and growth } \\
\text { pattern }\end{array}$ \\
\hline Control & No sterilant & -- & NIL & Contaminated \\
\hline \multirow{5}{*}{ Bavistin } & 0.01 & 10 & $26.8 \pm 1.56^{\mathrm{a}}$ & Non-uniform, contaminated \\
\hline & 0.05 & 10 & $51.6 \pm 1.08^{d}$ & Healthy, uniform \\
\hline & 0.1 & 10 & $55.4 \pm 1.12^{\mathrm{d}}$ & Healthy, uniform \\
\hline & 0.2 & 10 & $45 \pm 0.84^{c}$ & Medium, non-uniform \\
\hline & 0.4 & 10 & $39 \pm 0.84^{b}$ & No shoot induction \\
\hline \multirow{5}{*}{$\begin{array}{l}\text { Mercuric } \\
\text { Cholride } \\
\left(\mathrm{HgCl}_{2}\right)\end{array}$} & 0.01 & 5 & $59.2 \pm 2.29^{\mathrm{bc}}$ & Non-uniform, Contaminated \\
\hline & 0.05 & 5 & $64.2 \pm 1.83^{\mathrm{c}}$ & Medium, uniform, contaminated \\
\hline & 0.1 & 5 & $73.2 \pm 1.56^{\mathrm{d}}$ & Healthy, uniform \\
\hline & 0.2 & 5 & $53.2 \pm 1.39^{\mathrm{b}}$ & Medium, non-uniform \\
\hline & 0.4 & 5 & $46 \pm 1.34^{\mathrm{a}}$ & No shoot induction \\
\hline \multirow{5}{*}{$\begin{array}{c}\text { Sodium } \\
\text { hypochlorite } \\
\text { (NaOCl) }\end{array}$} & 2 & 10 & $32.6 \pm 1.03^{\mathrm{a}}$ & $\begin{array}{l}\text { Medium, non-uniform, } \\
\text { contaminated }\end{array}$ \\
\hline & 4 & 10 & $65.6 \pm 1.50^{d}$ & Healthy, uniform \\
\hline & 6 & 10 & $66 \pm 1.41^{\mathrm{d}}$ & Healthy, uniform \\
\hline & 8 & 10 & $56.2 \pm 1.46^{\mathrm{c}}$ & Healthy, non-uniform \\
\hline & 10 & 10 & $51.4 \pm 0.75^{\mathrm{b}}$ & Medium, non-uniform \\
\hline \multirow{5}{*}{$\begin{array}{l}\text { Ethanol } \\
\text { (EtOH) }\end{array}$} & 60 & 1 & $40.8 \pm 1.07^{b}$ & Medium, non-uniform \\
\hline & 70 & 1 & $51.6 \pm 1.72^{\mathrm{d}}$ & Healthy, uniform \\
\hline & 80 & 1 & $45.8 \pm 1.16^{\mathrm{c}}$ & Medium, non-uniform \\
\hline & 90 & 1 & $43.2 \pm 1.46^{\mathrm{bc}}$ & Medium, non uniform \\
\hline & 100 & 1 & $33 \pm 0.71^{\mathrm{a}}$ & Medium, non-uniform \\
\hline $\begin{array}{c}\text { Combination } \\
\text { (Bavistin+HgC } \\
\mathrm{l}_{2}+\mathrm{NaOCl}+\mathrm{EtO} \\
\mathrm{H})\end{array}$ & $(0.1+0.1+6+70)$ & $(10+5+10+1)$ & $85.4 \pm 1.29^{\mathrm{e}}$ & $\begin{array}{l}\text { Healthy, uniform, vigorous } \\
\text { shoots }\end{array}$ \\
\hline
\end{tabular}


Fig.1 Effect of various concentrations of different sterilant on culture survival

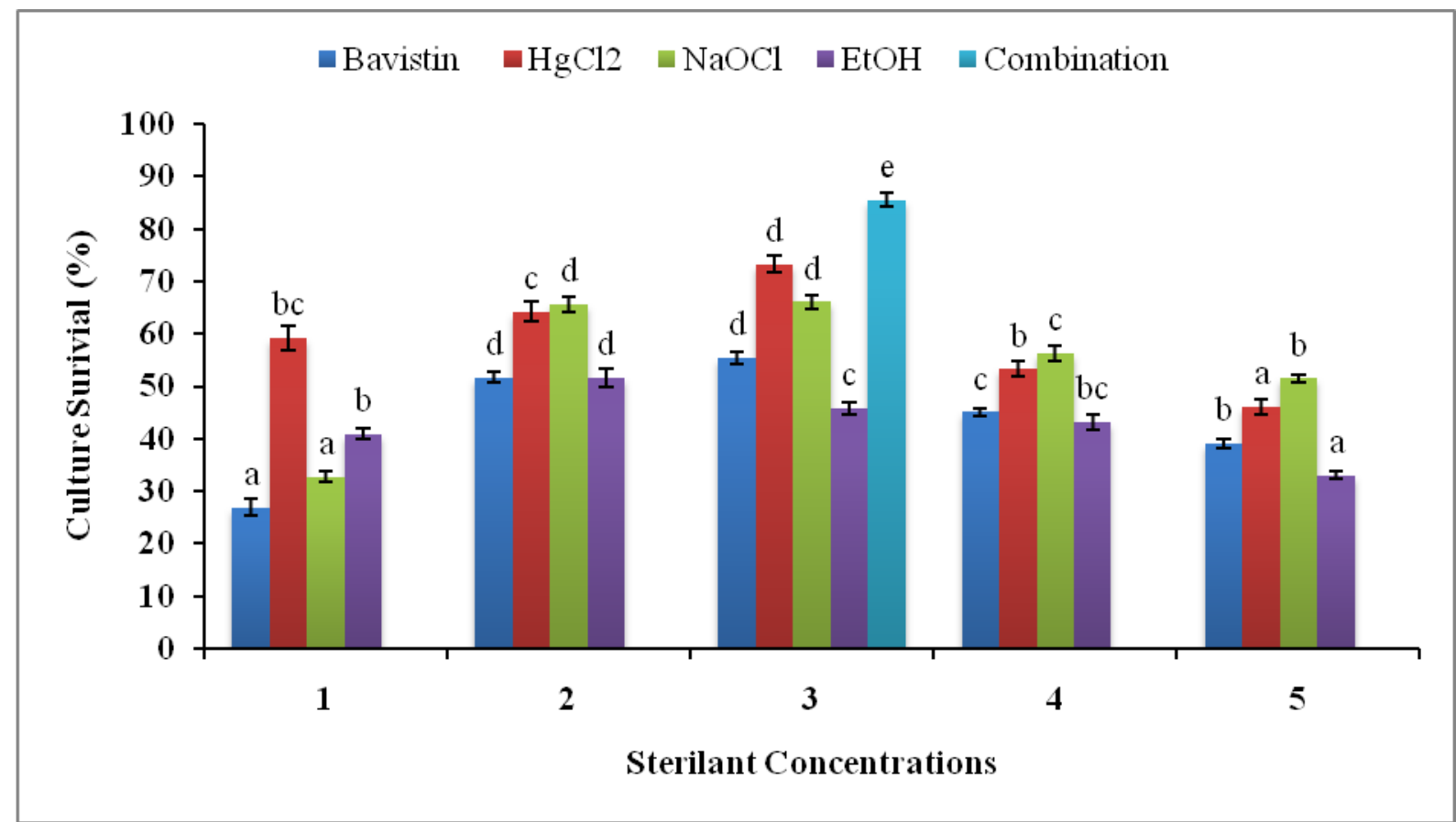

Note: Sterilant Concentrations-

$1=0.01 \%$ for Bavistin and $\mathrm{HgCl}_{2}, 2 \%$ for $\mathrm{NaOCl}, 60 \%$ for $\mathrm{EtOH}$;

$2=0.05 \%$ for Bavistin and $\mathrm{HgCl}_{2}, 4 \%$ for $\mathrm{NaOCl}, 70 \%$ for $\mathrm{EtOH}$;

$3=0.1 \%$ for Bavistin and $\mathrm{HgCl}_{2}, 6 \%$ for $\mathrm{NaOCl}, 80 \%$ for $\mathrm{EtOH}$;

$4=0.2 \%$ for Bavistin and $\mathrm{HgCl}_{2}, 8 \%$ for $\mathrm{NaOCl}, 90 \%$ for $\mathrm{EtOH}$;

$5=0.4 \%$ for Bavistin and $\mathrm{HgCl}_{2}, 10 \%$ for $\mathrm{NaOCl}, 100 \%$ for $\mathrm{EtOH}$

Combination $=0.1 \%$ Bavistin $+0.1 \% \mathrm{HgCl}_{2}+6 \% \mathrm{NaOCl}+70 \% \mathrm{EtOH}$

Fig.2 Shoot establishment and multiplication

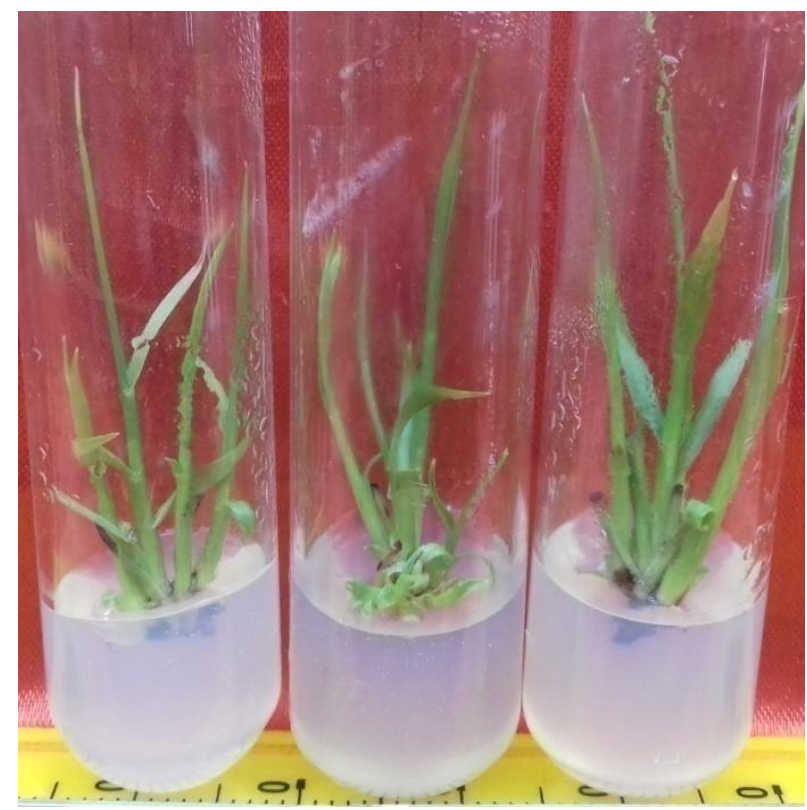


The explants treated with various concentrations of $\mathrm{HgCl}_{2}$ showed culture survival percent within a range of 46 to $73.2 \%$ and found to be statistically different $(p<0.05)$ (Table 1 and Fig. 1). The explants treated with $0.1 \% \mathrm{HgCl}_{2}$ for $5 \mathrm{~min}$ showed a significant $(p<0.05)$ increase in culture survival percent $(73.2 \%)$ with healthy and uniform shoot growth in comparison to other treatments. Similar findings were reported by Sawant and Tawar (2011). Babaei et al., (2013) and Tiwari et al., (2012) also reported the $0.1 \% \mathrm{HgCl}_{2}$ for $5 \mathrm{~min}$ as effective treatment for explant surface sterilization with minimum tissue necrosis. However, explants treated with $0.05 \% \mathrm{HgCl}_{2}$ also showed higher culture survival as compared to other $\mathrm{HgCl}_{2}$ treatments but a microbial growth after one week was observed. The significantly $(p>0.05)$ lesser culture survival percent sometimes no shoot induction was obtained in explants treated with $0.4 \% \mathrm{HgCl}_{2}$. Increase in $\mathrm{HgCl}_{2} \%$ found to be resulted in deleterious effect on explants survival, explants turned into brownish black and failed to proliferate during incubation as a result of tissue necrosis. It may me the results of bleaching action of two chloride atoms and ions that combine strongly with proteins and cause necrosis to plant tissues. The findings of this study are in agreement with earlier researcher reports of Johnson et al., (2011) and Wesely et al., (2011).

Sodium hypochlorite $(\mathrm{NaOCl})$ is a compound effectively used for water purification as disinfectants also used in various concentrations to show the effect on explant sterilization. The culture survival was found to be ranged from 32.6 to $65.6 \%$ (Table 1 and Fig. 1) under studied concentrations of $\mathrm{NaOCl}$. The explants treated with $6 \% \mathrm{NaOCl}$ for $10 \mathrm{~min}$ showed a significantly $(p<0.05)$ higher culture survival percent $(66 \%)$ and uniform shoot growth as compared to other $\mathrm{NaOCl}$ treatments. However, culture survival percent was significantly $(p>0.05)$ in explants treated with 4 and $6 \% \mathrm{NaOCl}$. A significant $(p<0.05)$ lesser culture survival percent was shown to be in explants treated with $2 \%$ $\mathrm{NaOCl}$. A significant $(p<0.05)$ increase in culture survival percent was shown with increasing $\mathrm{NaOCl}$ concentration but shoot growth was non-uniform. Similar findings also reported by Reda et al., (2004) and suggested sodium hypochlorite as an effective surface sterilant for sterilization. Wlodkowski and Rosenkranz (1975) and Danso et al., (2011) reported $\mathrm{NaOCl}$ diluted with water lead to formation of $\mathrm{HClO}$ and resulted in lethal DNA damage (Dukan et al., 1999).

Ethanol is used as strong phytotoxic sterilizing agent. Earlier researchers also reported that alcohols have higher bactericidal activity as compared to other bacteriostatic agents against bacterial vegetative cells but do not destroy spore cells (Bloomfield, 1978). In present study, various concentration of ethanol had been used to determine its effectiveness on explant sterilization that found to be ranged from 33 to $51.6 \%$ (Table 1 and Fig. 1). The explants treated with $70 \%$ ethanol for $1 \mathrm{~min}$ showed a significantly $(p<0.05)$ higher survival percent $(51.6 \%)$ with healthy and uniform shoot growth as compared to other EtOH treatments but shoot induction was slower. However, minimum culture survival percent and non-uniform shoot growth was to be noted in explants treated with $100 \%$ of Ethanol.

A significantly $(p<0.05)$ higher culture survival percent $(85.4 \%)$ with vigorous shoot growth as compared to other treatments was observed in explants treated with a combination of $0.1 \%$ Bavistin for $10 \mathrm{~min}$ followed by $0.1 \% \mathrm{HgCl}_{2}$ for $5 \mathrm{~min}, 6 \%$ $\mathrm{NaOCl}$ for $10 \mathrm{~min}$ and $70 \% \mathrm{EtOH}$ for $1 \mathrm{~min}$ with subsequent three washing of de-ionized water after each treatment (Table 1 and Fig. 1). The regenerated shoots were healthy and 
green coloured and aseptic tissue growth was observed and media was apparent clear with no turbidity. However, treatment with single sterilant resulted in good shoot proliferation but subsequently failed to control microbial contamination in second week (Fig. 2). No survival was observed in explants inoculated without any sterilant treatment. The results under study also indicate that contamination percent was reduced when explants were treated with either of $0.2 \%$ Bavistin, $0.2 \%$ $\mathrm{HgCl}_{2}$ or $8 \% \mathrm{NaOCl}$ alone but at the same time there was adverse effect on tissue growth was to be seen due to increased necrosis leading to failure of shoot induction. The Variations in shoot induction and proliferation was the result of sterilant impact and damage to the explants during treatment.

In present study, each sterilant differed in its activity on explants surface sterilization that suggest sterilization process differs with tissue and type of explant. The sterilants combination used under study was found to me more effective for meristem shoot tip explants sterilization and culture establishment in sugarcane variety Co 0118.

\section{References}

Adilakshmi, D., Charumati, M., Jayachandra, K. and Bebi, P. 2015. Influence of various compounds on media sterilization in sugarcane meristem tip culture. Int. J. Innov. Sci. Eng. Technol. 2(9): 355-367.

Altan, F., Bürün, B. and Sahin, N. 2010. Fungal contaminants observed during micropropagation of Lilium candidum $\mathrm{L}$. and the effect of chemotherapeutic substances applied after sterilization. Afri. J. Biotechnol. 7: 991-995.

Anburaj, J., Singh C.R., Kuberan, T., Sundaravadivelan, C. and Kumar, P. 2011. Effects of plant growth regulators on callus induction from leaf explants of Cleome viscose. Res. J. Pharm. Biol. Chem. Sci. 2: 576.
Ayele, Y.Z. and Tefera, W. 2018. Low cost sterilization technique and in vitro initiation of vanilla (Vanilla planifolia Andr.). $J$. Agri. Sci. Food Res. 9: 277.

Babaei, N., Abdullah, N.A.P., Saleh, G. and Abdullah, T.L. 2013. Control of contamination and explant browning in Curculigo latifolia in vitro cultures. J. Med. Plants Res. 7: 448-454.

Belete, Y.Z. and Kalu, H. 2015. Protocol optimization for surface sterilization of sugarcane variety (B-52/298). Int. Letter Chem. Phys. Astr. 48: 50-60.

Bloomfield, S.F. 1978. A review: The use of disinfectants in the home. J. Appl. Bacteriol. 4(1): 38 .

Chatenet, M., Delage C. and Ripolles, M. 2001. Detection of sugarcane yellow leaf curl virus in quarantine and production of virusfree sugarcane by apical meristem culture. Plant Disease. 85(11): 1177-1180.

Danso, K.E., Azu, E., Elegba, W., Asumeng, A., Amoatey, H.M. and Klu, G.Y.P. 2011. Effective decontamination and subsequent plantlet regeneration of sugarcane (Sacchrum officinarum L.) in vitro. Int. J. Integr. Biol. 11: 90-96.

Dukan, S., Belkin, S. and Touati, D. 1999. Reactive oxygen species are partially involved in the bactericidal action of hypochlorous acid. Archives Biochem. Biophys. 367: 311-316.

FAOSTAT 2017. Statistical division: production domain- Crops. Food and Agriculture Organization of the Unite Nations: FAO Statistical Databases. http://faostat.fao.org. Accesed date 06June 2019.

Gallo-Meagher, M., English R.G. and Abouzid, A. 2000. Thidiazuron stimulates shoot regeneration of sugarcane embryogenic callus. In Vitro Cell. Developmental Biol. Plant. 36: 37-40.

George, M.W. and Tripepi, R.R. 2001. Plant preservative mixture ${ }^{\mathrm{TM}}$ can affect shoot regeneration from leaf explants of chrysanthemum, European birch, and rhododendron. Hort. Sci. 36(4): 768-769.

Ghatge, S., Kudale, S., Dalvi, S. and Dixit, G. 2014. Effect of chitosan elicitation on Alizarin production in hairy root cultures of 
Rubia cordifolia L. J. Chitin and Chitosan Sci. 2(1): 62-69.

Jalaja, N.C., Neelamathi, D. and Sreenivasan, T.V. 2008. Micropropagation for quality seed production in sugarcane. In: Manual on Micropropagation for quality seed production in sugarcane in Asia and the pacific. Food and Agriculture Organization of the United Nations (FAO), Rome. $p p$. 130.

Johnson, M., Wesely, E.G., Kavitha, M.S. and Uma, V. 2011. Antibacterial activity of leaves and intermodal callus extracts of Mentha arvensis L. Asian Pacific J. Trop. Med. 4: 196-200.

Khatun, M.M., Tanny, T., Razzak, A.M., Alam, M.F., Uddin, M.E., Amin. R. and Yesmin, S. 2016. Standardization of in vitro sterilization procedures for micropropagation of Ginger (Zingiber officinale Rosc.), Int. J. App. Biol. Pharma. Technol. 7: 1

Murashinge, T. and Skoog, F. 1962. A revised medium for rapid growth and bio assays with tobacco tissue cultures. Physiol. Planta. 15: 473-497.

Panhwar. F. 2005. Acclimatization and establishment of micropropagation plants. By Digital Verlag Gmbh, Germany. pp. 1-8.

Preethi, D., Sridhar, T.M. and Naidu, C.V. 2011. Efficient protocol for indirect shoot regeneration from leaf explants of Stevia rebaudiana (Bert.) - An important calorie free bio sweetner, J. Phytol. 3: 56-60.

Reda, E.A., Moghaieb, S.H. and Fujita, K. 2004. Shoot regeneration from GUS-transformed tomato (Lycopersicon esculentum) hairy root. Cellular and Molecul. Biol. Letters. 9: 439-449.

Sawant, R.A. and Tawar, P.N. 2011. Use of sodium hypochlorite as media sterilant in sugarcane micropropagation at commercial scale. Sugar Tech. 13: 27-35.

Schenck, S. and Lehrer, A.T. 2000. Factors affecting the transmission and spread of sugarcane yellow leaf virus. Plant Disease. 84(10): 1085-1088.

Sengar, R.S., Sengar, K. and Garg, S.K. 2012. Biotechnology intervention for boosting sugarcane production. Res. J. Agri. Sci. 3(3): 593-599.

Sengar, R.S., Sengar, K. Rao, V.P. and Gupta, S. 2011. Biotechnological approaches for high sugarcane yield. Plant Sci. Feed. 1(7): 101111.

Suaib, S. and Suaib, N.F. 2019. Non-autoclaved sterilization procedures of sugarcane tissue in vitro culture. J. Appl. Sci. 19(5): 434440.

Thorat, A.S., Muley, A.B., Shingote, P.R., Nalavade, V.M. and Babu, K.H. 2016. Establishment of sterilization method for emergent quality of sugarcane (Saccharum officinarum L.) in an efficient micropropagation system. Res. J. Pharma. Biol. Chem. Sci. 7(2): 1122-1135.

Tiwari, A.K., Tripathi, S., Lal, M. and Mishra, S. 2012. Screening of some chemical disinfectants for media sterilization during in-vitro micropropagation of sugarcane. Sugar Tech. 14: 364-369.

Wesely, E.G., Johnson, M., Kavitha, M.S. and Selvan, N. 2011. Micropropagation of Alternanthera sessilis L. using shoot tip and nodal segments. Iranian J. Biotechnol. 9: 206-212.

Wlodkowski, T.J. and Rosenkranz, H.S. 1975. Mutagenicity of sodium hypochlorite for Salmonella typhimurium. Mutat. Res. 31: $39-42$.

\section{How to cite this article:}

Devendra Kumar, Rakesh Singh Sengar, Manoj Kumar Yadav, Pooranchand, Gopal Singh and Shalani Gupta. 2019. Evaluation of Sterilant Effect on In-vitro Culture Establishment in Sugarcane Variety Co 0118. Int.J.Curr.Microbiol.App.Sci. 8(07): 1226-1233.

doi: https://doi.org/10.20546/ijcmas.2019.807.146 